\title{
PEMANFAATAN ZEOLIT DAN SILIKA SEBAGAI MATERIAL MEMBRAN FILTRASI UNTUK MENURUNKAN KONSENTRASI WARNA LIMBAH CAIR BATIK
}

\author{
ZEOLITE AND SILICA AS MATERIAL FOR FILTER MEMBRANE \\ TO REMOVE COLOR FROM BATIK WASTEWATER
}

\author{
Noven Pramitasari*) dan Alia Damayanti \\ Jurusan Teknik Lingkungan, Institut Teknologi Sepuluh Nopember Surabaya, \\ Kampus ITS Keputih Sukolilo, Surabaya, 60111 \\ ${ }^{*}$ Email: noven.pramitasari@gmail.com
}

\begin{abstract}
Abstrak
Pembuangan limbah cair indusri yang tidak sesuai dengan baku mutu secara langsung ke badan air dapat menyebabkan pencemaran. Salah satu industri yang menghasilkan limbah cair adalah industri batik. Limbah industri batik memiliki konsentrasi warna yang memerlukan pengolahan sebelum dibuang ke badan air. Salah satu teknologi pengolahannya adalah menggunakan membran filtrasi. Untuk memperkecil biaya pembuatan dan meningkatkan masa pakai membran filrasi maka digunakan zeolit dan silika sebagai bahan pembuat membran. Pengujian membran dilakukan dengan reaktor cross flow untuk meminimalkan biaya operasi. Tujuan penelitian ini adalah untuk menentukan perbandingan massa penambahan silika, kecepatan centrifuge dan persen volume limbah cair untuk menurunkan konsentrasi warna pada limbah cair batik dengan mengukur nilai rejeksi terhadap konsentrasi warna. Nilai rejeksi membran terhadap konsentrasi warna sebersar 92,68\% diperoleh pada membran dengan massa penambahan silika 3\%, keceparan centrifuge 600 RPM dan persen limbah cair $100 \%$.
\end{abstract}

Kata kunci: limbah industri, membran, rejeksi, silika, zeolit

\begin{abstract}
Wastewater disposal from industries causes contamination of surface water. One of the industries that produce liquid waste is batik industry. Batik industry which is part of the textile industry that has a high level of color concentration. Before disposing to enviroment, wastewater must be treated. Membrane filtration is one of technology to treat industrial wastewater. Unfortunately, commercial membrane filtration commomly used is highly priced. Therefore, zeolite and silica can be used as cheaper alternative material for membrane. Whereas to minimize the operating costs and increase the life time of the membrane, filtration operated in a cross flow reactor. The purpose of this study was to determine the mass ratio of silica addition, centrifugation speed and percent of volume of wastewater to reduce color concentration by measuring the value of filter rejection of color concentration. A 92,68\% rejection value of color concentration was achieved when mass addition of silica was 3\%, centrifugation speed was 600 RPM and wastewater volume was $100 \%$.
\end{abstract}

Keywords: membrane, rejection, silica, wastewater, zeolite

\section{PENDAHULUAN}

Meningkatnya pertumbuhan industri di Indonesia memberikan pengaruh bagi terpenuhinya segala kebutuhan yang diperlukan oleh masyarakat indonesia. Selain memberikan keuntungan, pesatnya pertumbuhan industri juga menimbulkan berbagai permasalahan terkait upaya limbah cair yang dihasilkan. Industi batik sebagai usaha kecil menengah (UKM) di Indonesia menghasilkan limbah cair. Salah satu limbah cair yang dihasilkan adalah limbah cair pewarnaan batik yang mengandung zat warna. Sama halnya dengan limbah cair tekstil yang 
lain, limbah cair batik menurut Rashidi dkk (2013) juga memiliki kandungan warna yang membutuhkan pengolahan sebelum dibuang ke badan air. Limbah cair yang dihasilkan tidak dapat secara langsung dibuang ke badan air karena mengandung zat pencemar dan zat warna yang dapat membahayakan manusia dan mencemari lingkungan.

Penelitian telah banyak dilakukan untuk mengolah limbah cair batik agar sesuai dengan baku mutu lingkungan yang ditetapkan oleh pemerintah. Metode pengolahan yang telah banyak diteliti adalah pengolahan secara kimia, biologi dan fisik. Salah satu metode pengolahan secara kimia yang telah dilakukan adalah dengan menggunakan metode elektrokoagulasi. Metode ini telah diteliti oleh Yulianto et al. (2009) dan mampu menurunkan konsentrasi warna sebesar $55 \%$. Pengolahan lain juga telah dilakukan oleh Setyaningsih (2007) dengan menggunakan proses koagulasi dengan koagulan $\mathrm{FeSO}_{4}$ dan $\mathrm{Ca}(\mathrm{OH})_{2}$. Kemudian dilanjutkan dengan proses fisik yaitu dengan adsorpsi. Akumulasi zat warna dan sifat tidak bisa didaur ulang pada adsorben merupakan kekurangan dari metode ini. Penambahan bahan-bahan kimia dalam pengolahan secara kimia juga dapat menimbulkan permasalahan baru bagi lingkungan.

Pengolahan limbah cair industri batik dan tekstil juga dapat menggunakan pengolahan biologis seperti penelitian Effendi et al. (2015) yang menggunakan Moringa oleifera sebagai koagulan untuk menurunkan turbidity limbah. Kekurangan dari proses pengolahan secara biologi adalah lamanya waktu yang diperlukan dalam proses pengolahan.

Penelitian menggunakan pengolahan fisik telah dilakukan oleh Setiawan et al. (2007) dengan menggunakan adsorben karbon- $\mathrm{TiO}_{2}$ untuk mereduksi warna pada limbah cair tekstil. Hasil penelitian ini mampu mereduksi 29,608 \% warna. Penelitian lain telah dilakukan oleh Fadhilah et al. (2015) dengan menggunakan solar photocatalytic process untuk limbah cair batik. Metode ini dapat menurunkan warna pada limbah cair batik. Sedangkan Penelitian yang telah dilakukan oleh Nordin et al. (2013) adalah pengolahan limbah cair batik dengan teknik oksidasi elektrokimia menggunakan plat logam. Metode ini efektif menurunkan sisa warna.

Metode pengolahan secara fisik lain yang banyak diteliti untuk mengolah limbah tekstil termasuk limbah cair batik adalah dengan menggunakan membran nanofiltrasi (Puspayana dan Damayanti, 2013). Membran banyak digunakan karena sederhana, ramah lingkungan dan kebutuhan energi yang rendah (Wenten, 2003).

Jenis membran yang efektif dan biasa digunakan untuk mereduksi warna adalah membran nanofiltrasi dan ultrafiltrasi (Liu et al., 2012 dan Dong et al., 2015). Membran ultrafiltrasi dan nanofiltrasi efektif untuk menghilangkan warna akan tetapi memiliki beberapa kelemahan yaitu adanya batas waktu penggunaan karena dapat terjadi fouling pada membran dan mahalnya biaya pengadaan membran.

Salah satu cara untuk mengatasi kekurangan pada pengaplikasian membran adalah dengan penggunaan material membran yang dapat meningkatkan waktu pakai membran dan meminimalkan harga jual membran. Salah satu material membran yang dapat digunakan adalah zeolit karena merupakan material alam yang mudah didapatkan dan lebih murah dari pada menggunakan membran polimer. Penambahan silika berfungsi untuk meningkatkan ratio $\mathrm{Si} / \mathrm{Al}$ membran zeolit sehingga meningkatkan daya saring pada membran filtrasi.

Zeolit dapat dimanfaatkan sebagai material filtrasi karena mampu memisahkan molekul berdasarkan ukuran, bentuk, polaritas dan derajat ketidakjenuhan. Zeolit dapat dimodifikasi dengan cara sintesis langsung untuk meningkatkan kandungan silika sehingga dapat meningkatkan sifat hidrofobik pada zeolit (Flanigen dkk, 2010). Zeolit merupakan salah satu contoh molecular sieves. molecular sieves adalah padatan berpori dengan ukuran dimensi molekul berkisar antara $0,3 \mathrm{~nm}$ sampai $2 \mathrm{~nm}$ (Flanigen dkk, 2010). Zeolit memiliki beragam ukuran dan struktur pori. Keberagaman tersebut 
disebabkan oleh variasi koneksi pada $\mathrm{TO}_{4}(\mathrm{Ti}=$ $\mathrm{Si}$ atau $\mathrm{Al}$ ) tetrahedral (Feng dkk, 2015).

Penelitian ini bertujuan untuk menentukan pengaruh penambahan silika, kecepatan centrifuge dan persen volume limbah cair untuk menurunkan konsentrasi warna pada limbah cair batik. Proses filtrasi dilakukan dengan pola aliran cross flow karena memerlukan biaya operasi yang lebih rendah.

\section{METODA}

Prosedur pertama adalah proses reduksi ukuran zeolit dan silika sampai berukuran ukuran 200 mesh. Setelah itu mencuci zeolit dan silika yang telah diaktivasi dengan $\mathrm{HCl}$ selama 12 jam secara terpisah untuk menghilangkan pengotor. Kemudian zeolit dan silika dicuci dengan aquadest dan ditumbuk sehingga didapatkan serbuk zeolit dan silika.

Serbuk zeolit dan silika dengan perbandingan massa silika sebesar $0,5 \%, 1,5$ dan 3\% massa zeolit dimasukkan ke dalam botol centrifuge kemudian ditambahkan 2-Propanol. Campuran tersebut dicentrifuge selama 20 menit dengan kecepatan centrifuge 200 dan $600 \mathrm{rpm}$. Selanjutnya, endapan dimasukkan ke beaker glass yang telah berisi larutan $\mathrm{NH}_{4} \mathrm{Cl}$ kemudian diaduk dengan magnetic stirrer selama 1 jam. Endapan zeolit dan silika ditambahkan polyvinyl alcohol dan polyethylene glycol lalu dipanaskan sampai mengental. Campuran kemudian dicetak dan diamkan sampai mengeras. Komposisi polyvinyl alcohol dan polyethylene glycol berpengaruh pada membran yang dihasilkan. Penambahan polyvinyl alcohol dapat memperbaiki struktur, meningkatkan kekuatan dan menstabilkan membran (Farha et al, 2012). Akan tetapi penambahan polyvinyl alcohol berlebih akan menghasilkan membran yang kuat tetapi tidak memiliki pori karena permukaan membran terlapisi oleh larutan polyvinyl alcohol. Sedangkan penambahan polyethylene glycol sebagai senyawa biocompatible, highly hydrophilic dan anti fouling dapat memperbanyak pori dan meningkatkan interkonektivitas pori pada membran (Liu dkk, 2012).
Membran yang telah jadi kemudian diujikan pada reaktor dengan aliran cross flow. Pengujian membran menggunakan limbah pewarnaan batik dengan persen volume limbah cair sebesar $100 \%$ dan $75 \%$. Skema aliran filtrasi dapat dilihat pada Gambar 1. Membran diletakkan ke dalam reaktor sebagai media filtrasi. Limbah dialirkan menggunakan rangkaian pipa polyvynil carbonate (PVC) yang dilengkapi dengan valve dan pressure gauge untuk mengatur tekanan dan arah aliran. Limbah ditempatkan ke dalam storage kemudian dialirkan dengan pola aliran cross flow. Aliran cross flow dipilih karena penggunaan tekanan yang lebih kecil sehingga dapat memperkecil biaya operasi. Selain itu juga dapat mencegah terjadinya fouling yang dapat menurunkan kinerja membran.

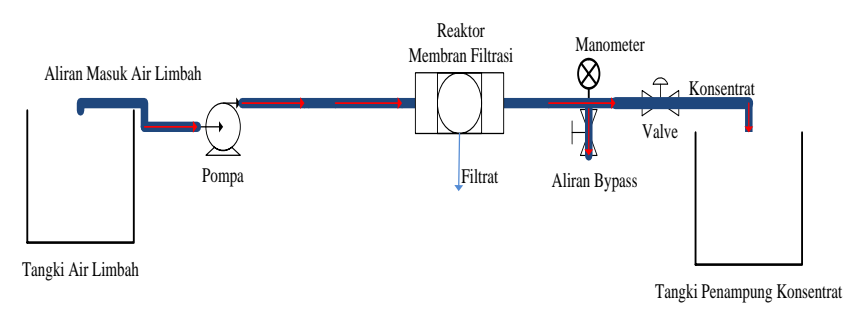

Gambar 1. Skema Filtrasi Membran Zeolit

Limbah yang telah diujikan pada reaktor crossflow menghasilkan permeat. Permeat yang dihasilkan tiap 20 menit selama 100 menit pengujian selanjutnya dianalisis untuk mengetahui konsentrasi warna.

Kemudian dilakukan karakterisasi membran menggunakan Scanning Electron Microscope dan Energy Dispersif X-ray. Scanning Electron Microscope merupakan salah satu instrument yang tepat untuk menguji, menganalisis morfologi dan struktur mikro padatan (Zhou dkk., 2007) sedangkan pengujian membran dengan energi dispersif X-ray dilakukan untuk mengetahui kandungan unsur tertahan pada membran. Energi dispersif X-ray telah terbukti menjadi alat yang berguna untuk menentukan komposisi kimia membran (Alonso et al., 2013). Setiap unsur memiliki emisi sinar-X yang khas dalam energi dan panjang gelombangnya sehingga dapat menentukan kandungan tiap unsur Ahkam (2011). 


\section{HASIL DAN PEMBAHASAN}

Membran yang telah dicetak dan didiamkan pada suhu ruang kemudian dioven pada suhu $70{ }^{\circ} \mathrm{C}$ selama 1 jam. Tujuan dari perlakuan ini adalah untuk menghilangkan kadar air yang terkandung pada membran sehingga dapat meningkatkan luas permukaan dan kepadatan membran. Secara fisik, membran memiliki karakteristik yang keras dan padat serta tekstur permukaan membran halus dan kering.

Membran diujikan pada reaktor dengan aliran cross flow selama 100 menit. Pengambilan permeat dilakukan setiap 20 menit sehingga didapatkan 5 sampel setiap kali pengujian membran. Diameter aktif membran sebagai media filtrasi adalah $2 \mathrm{~cm}$ sesuai dengan lubang water mur. Permukaan membran yang telah diuji berwarna merah dan terdapat padatan-padatan yang menempel.

Nilai permselektivitas membran terhadap zat warna pada limbah cair batik dapat dilihat dari perubahan warna secara visual maupun menggunakan spektrofotometer pada permeat yang dihasilkan. Pada penelitian ini analisis warna dilakukan dengan spektrofotometer. Membran terbukti dapat menyaring zat warna merah yang digunakan pada proses pewarnaan batik.

Nilai permseletivitas membran terhadap zat warna pada limbah cair pewarnaan batik dapat dilihat pada Gambar 2 sampai 5. Pengaruh penambahan silika pada zeolit sebagai material membran dengan kecepatan centrifuge $200 \mathrm{rpm}$ dapat dibandingkan dari Gambar 2 sedangkan membran dengan kecepatan $600 \mathrm{rpm}$ dapat dilihat pada Gambar 2 3. Gambar menunjukkan bahwa penambahan silika sebesar 3\% dari massa zeolit memiliki nilai rejeksi yang lebih besar dari pada penambahan silika sebesar 0,5 dan $1,5 \%$. Pada pengujian dengan konsentrasi limbah cair $75 \%$, membran dengan kecepatan centrifuge 200 rpm ataupun $600 \mathrm{rpm}$ menunjukkan hubungan yang sama. Hubungan tersebut dapat dilihat ada Gambar 4 dan 5 yaitu bahwa massa penambahan silika 3\% dari massa zeolit memiliki nilai rejeksi yang paling besar.

Pengaruh variabel kedua yaitu kecepatan centrifuge pada nilai rejeksi warna dapat dilihat dari Gambar 2 dibandingkan dengan Gambar 3 dan Gambar 4 dibandingkan dengan Gambar 5. Perbandingan Gambar 2 dan 3 menunjukkan bahwa nilai rejeksi lebih tinggi dimiliki oleh membran dengan kecepatan centrifuge $600 \mathrm{rpm}$. Seperti halnya pada konsentrasi limbah cair $100 \%$, pengujian membran dengan kecepatan centrifuge $600 \mathrm{rpm}$ pada konsentrasi limbah cair $75 \%$ memiliki nilai rejeksi warna yang lebih tinggi. Hal ini dapat dilihat pada Gambar 4 dan 5.

Hubungan variabel yang ketiga adalah pengaruh konsentrasi limbah cair pada pengujian membran fiiltrasi. Hubungan ini dapat dilihat dengan membandingakan Gambar 2 dan 3 serta Gambar 4 dan 5. Nilai rejeksi warna lebih besar ketika membran diujikan pada limbah dengan konsentrasi $100 \%$. Selisih perbedaan nilai rejeksi antara pengujian dengan limbah cair $100 \%$ dan $75 \%$ pada kecepatan centrifuge 600 rpm berkisar antara $24-26 \%$.

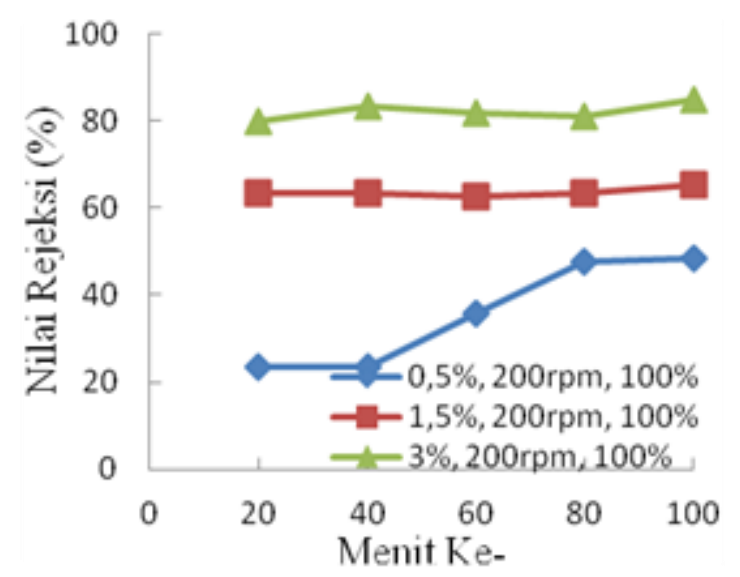

Gambar 2. Perbedaan Nilai Rejeksi Warna Penambahan Silika Membran Dengan Kecepatan Centrifuge 200 rpm dan Konsentrasi Limbah $100 \%$. 


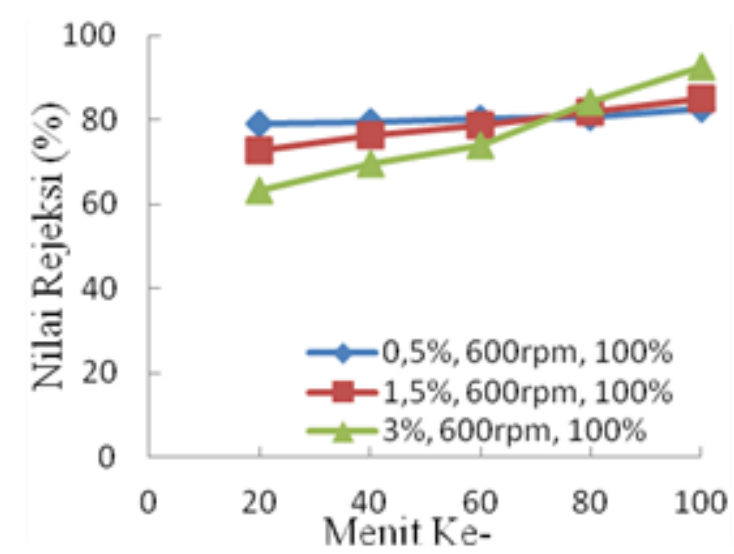

Gambar 3. Perbedaan Nilai Rejeksi Warna Penambahan Silika Membran Dengan Kecepatan Centrifuge 600 rpm dan Konsentrasi Limbah $100 \%$
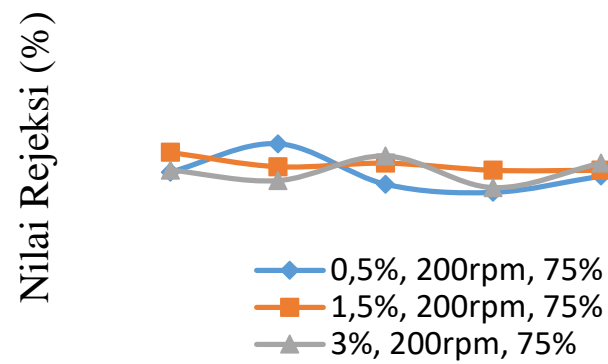

Menit Ke-

Gambar 4, Perbedaan Nilai Rejeksi Warna Penambahan Silika Membran Dengan Kecepatan Centrifuge $200 \mathrm{rpm}$ dan Konsentrasi Limbah $75 \%$.

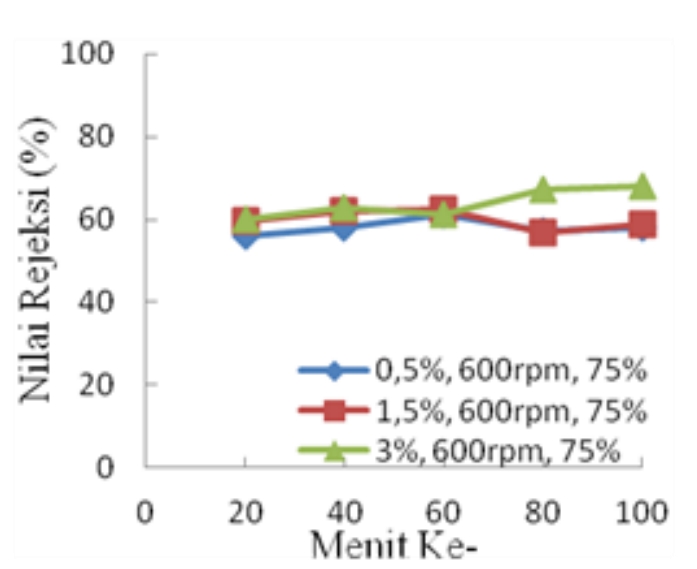

Gambar 5. Perbedaan Nilai Rejeksi Warna Penambahan Silika Membran Dengan Kecepatan Centrifuge $600 \mathrm{rpm}$ dan Konsentrasi Limbah $75 \%$
Hasil dari uji SEM yang telah dilakukan menunjukkan adanya penutupan pada pori-pori membran. Penutupan pada pori-pori membran diakibatkan menempelnya padatan tersuspensi dan zat warna yang ada pada limbah cair. Hal ini dapat dilihat pada Gambar 6 dan 7. Gambar 6 merupakan perbesaran permukaan membran sebelum difiltrasi sedangkan Gambar 7 menampilkan permukaan membran setelah digunakan sebagai media filtrasi limbah cair batik. Nilai perbesaran gambar adalah 1000 kali perbesaran. Perbandingan gambar menunjukkan mulai terjadinya fouling akibat menempelnya bahan organik dan anorganik dari limbah cair batik.

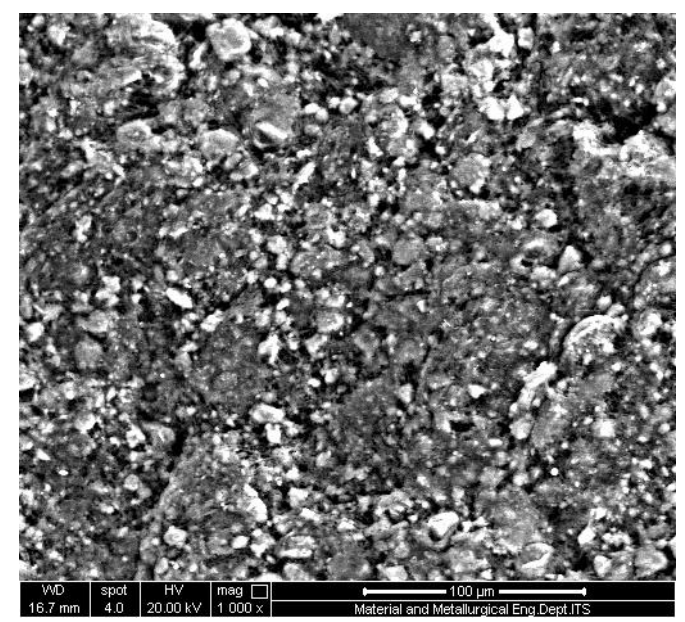

Gambar 6. Permukaan Membran Sebelum Filtrasi (Perbesaran 1000 kali).

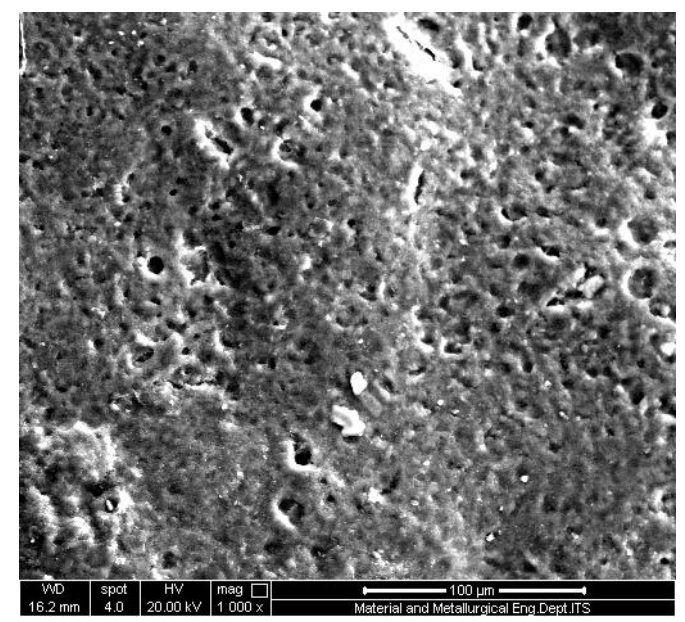

Gambar 7. Permukaan Membran Setelah Filtrasi (Perbesaran 1000 kali) 
Hasil analisis EDX menunjukkan adanya unsurunsur yang tersaring oleh membran. Gambar 8 dan 9 menunjukkan perbedaan kandungan unsur membran sebelum dan sesudah filtrasi. Gambar 8 adalah hasil EDX dari membran sebelum filtrasi sedangkan Gambar 9 merupakan hasil EDX dari membran setelah digunakan dalam proses filtrasi limbah cair batik. Perbandingan kandungan unsur menunjukkan adanya kandungan bahan organik dan logam berat dari zat warna yang tertahan pada membran. Gambar 8 menunjukkan bahwa rasio $\mathrm{Si} / \mathrm{Al}$ pada membran adalah berkisar 6,5. Setelah mengalami proses filtrasi, terdapat peningkatan unsur-unsur lain seperti nilai C, Ag, Cd, Sn, Fe, P, Zn, Mg, Al. Hal ini menunjukkan bahwa membran mampu penyaring unsur organik maupun logam berat yang terdapat pada limbah cair pewarnaan batik.

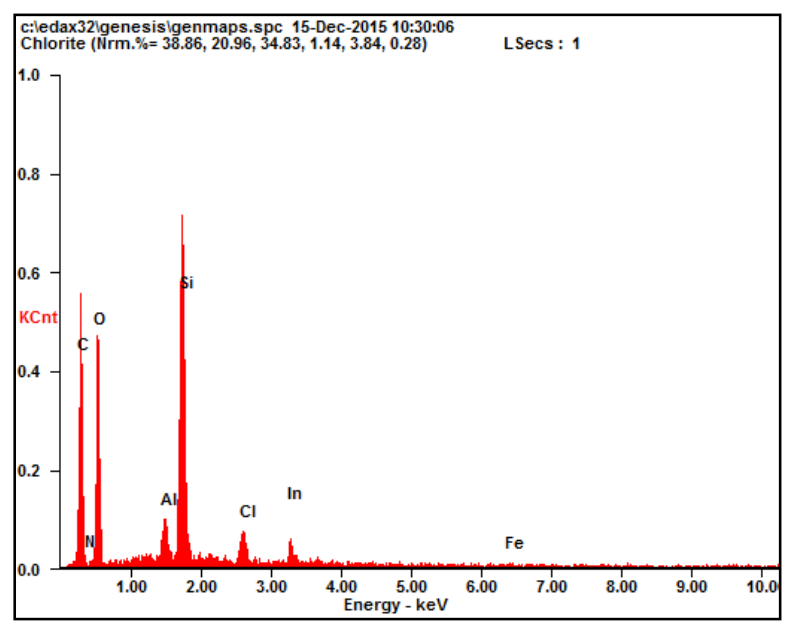

Gambar 8. Hasil EDX Kandungan Unsur Membran Sebelum Filtrasi.

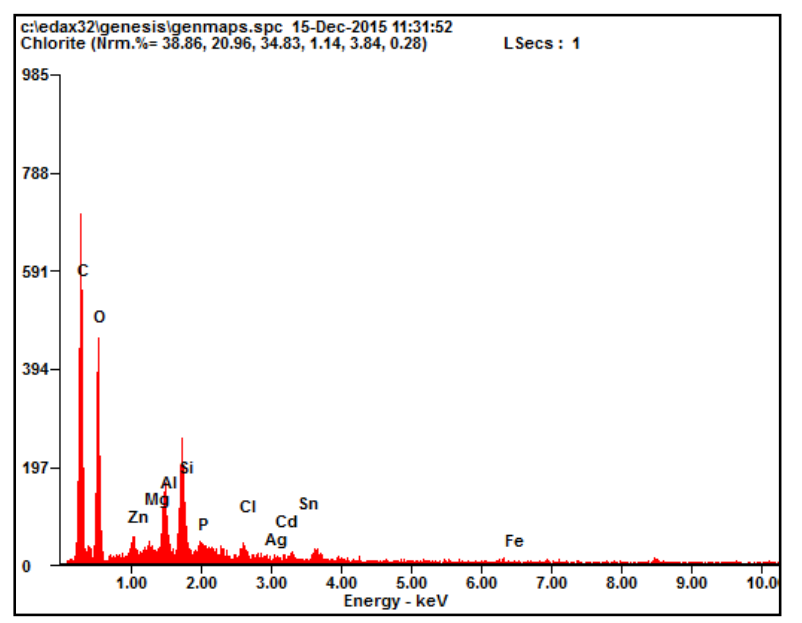

Gambar 9. Hasil EDX Kandungan Unsur Membran Setelah Filtrasi.
Analisis pengaruh variabel penelitian dilakukan dengan menggunakan analisis statistik. Analisis yang digunakan pada penelitian ini adalah metode Analysis of Variance (Anova). Metode Anova diujikan menggukan program IBM SPSS 20. Prosedur Anova menggunakan variabel numerik tunggal yang diukur dari sejumlah sampel untuk menguji hipotesis nol dari populasi yang (diperkirakan) memiliki rata-rata hitung (mean) sama. Variabel yang digunakan harus berupa variabel kuantitatif. Analisis Anova dijabarkan per pengaruh massa penambahan silika, kecepatan centrifuge dan persen volume limbah cair terhadap konsentrasi warna.

Sebelum uji statistik menggunakan metode Anova, data penelitian terlebih dahulu harus dilakukan uji normalitas. Uji normalitas dilakukan untuk mengetahui apakah data terdistribusi dengan normal. Jika data terdistribusi nornal maka dapat dilanjutkan dengan uji statistik menggunakan Metode Anova. Hasil uji normalitas menunjukkan data pada penelitian ini terdistribusi normal sehingga bisa diuji dengan metode Anova.

Pada analisis Anova terlebih dahulu ditentukan hipotesis untuk setiap variasi. Tingkat kesalahan ( $\alpha$ ) ditentukan sebesar 5\%. Bentuk hipotesis rancangan Faktorial yang digunakan dalam analisis sebagai berikut.

Hipotesis 1 (Efek massa penambahan silika terhadap nilai rejeksi Warna)

$\mathrm{H}_{0}$ : efek dari massa penambahan silika pada penambahan 0,5 \% massa zeolit = penambahan $1,5 \%$ massa zeolit $=$ penambahan $3 \%$ massa zeolit (massa penambahan silika tidak berpengaruh terhadap nilai rejeksi warna).

$\mathrm{H}_{1}$ : paling tidak ada satu efek massa penambahan silika yang berbeda (massa penambahan silika signifikan berpengaruh terhadap nilai rejeksi warna).

Hipotesis 2 (Efek kecepatan centrifuge terhadap nilai rejeksi warna)

$\mathrm{H}_{0}$ : efek dari kecepatan centrifuge pada level $200 \mathrm{rpm}=$ level $600 \mathrm{rpm}$ (kecepatan centrifuge tidak berpengaruh terhadap nilai rejeksi warna) 
$\mathrm{H}_{1}$ : paling tidak ada satu efek kecepatan centrifuge yang berpengaruh (kecepatan centrifuge signifikan berpengaruh terhadap nilai rejeksi warna).

Hipotesis 3 (Efek persen volume limbah cair terhadap nilai rejeksi warna)

$\mathrm{H}_{0}$ : efek dari persen volume limbah cair pada level 100\% = level 75\% (konsentrasi limbah cair tidak berpengaruh terhadap nilai rejeksi warna)

$\mathrm{H}_{1}$ : paling tidak ada satu efek konsentrasi limbah cair yang berpengaruh (konsentrasi limbah cair signifikan berpengaruh terhadap nilai rejeksi warna).

Penolakan $\mathrm{H}_{0}$ terjadi jika nilai signifikansi pada tabel Anova lebih kecil dari nilai $\alpha$. Dengan menggunakan tingkat kesalahan $\alpha$ sebesar 5\% $(0,05)$, diperoleh statistik uji pada Tabel 1 . Berdasarkan Tabel 1 diperoleh hasil bahwa nilai signifikansi untuk massa penambahan silika, kecepatan centrifuge, dan konsentrasi limbah cair berpengaruh terhadap nilai rejeksi warna. Selanjutnya dilakukan analisis Turkey untuk melihat perbedaan hanya dilakukan pada faktor massa penambahan silika, kecepatan centrifuge, dan konsentrasi limbah cair.

Tabel 1. Anova Faktorial 4 Faktor (Terhadap Nilai Rejeksi Warna)

\begin{tabular}{lrr}
\hline \multicolumn{1}{c}{ Source } & Mean Square & \multicolumn{1}{c}{ Sig. } \\
\hline Corrected Model & 2355,164 &, 000 \\
\hline Intercept & 456707,110 &, 000 \\
\hline Massa & 1541,384 &, 000 \\
\hline Kecepatan & 7562,533 &, 000 \\
\hline Persen volume & 7554,914 &, 000 \\
\hline Error & 110,590 & \\
\hline Total & & \\
\hline Corrected Total & & \\
\hline
\end{tabular}

Analisis Turkey digunakan untuk mengetahui perbedaan level di masing-masing faktor, sehingga dapat diketahui level mana yang memberi efek berbeda terhadap nilai rejeksi warna. Analisis tukey selengkapnya dijelaskan sebagai berikut. Pada analisis Turkey juga digunakan rancangan hipotesis $\mathrm{H}_{0}$ dan $\mathrm{H}_{1}$. Bentuk rancangan hipotesis yang digunakan dalam analisis yaitu sebagai berikut.

\section{Hipotesis untuk Massa Penambahan Silika}

$\mathrm{H}_{0}: \quad \mu_{\mathrm{i}}=\mu_{\mathrm{j}}$ (rata-rata nilai rejeksi warna sama antara level $0,5 \%$, level $1,5 \%$, dan level $3 \%$ )

$\mathrm{H}_{1}: \mu_{\mathrm{i}} \neq \mu_{\mathrm{j}}$ (rata-rata nilai rejeksi warna berbeda antara $0,5 \%$, level 1,5\%, dan level 3\%)

Penolakan $\mathrm{H}_{0}$ terjadi jika nilai signifikansi pada tabel Anova lebih kecil dari nilai $\alpha$. Pada analisis ini ditentukan nilai $\alpha$ adalah 0,05. Data hasil statistik yang diperoleh ditunjukkan pada Tabel 1.

Tabel 2 menjelaskan bahwa semua level massa penambahan silika mempunyai nilai yang kurang dari nilai $\alpha$. Hal ini menandakan bahwa pada semua level massa penambahan silika (level $0,5 \%$, level $1,5 \%$, dan level $3 \%$ ) mempunyai efek terhadap nilai rejeksi warna membran.

Tabel 2. Analisis uji Turkey untuk Massa Penambahan Silika (Terhadap Nilai Rejeksi Warna)

\begin{tabular}{|c|c|c|c|}
\hline (I) & (J) & & \\
\hline massa_warna & massa_warna & Std. Error & Sig. \\
\hline 100 & 2,00 & 2,35149 & ,004 \\
\hline 1,00 & 3,00 & 2,35149 & 000 \\
\hline م 0 & 1,00 & 2,35149 &, 004 \\
\hline 2,00 & 3,00 & 2,35149 & , 123 \\
\hline 300 & 1,00 & 2,35149 &, 000 \\
\hline 3,00 & 2,00 & 2,35149 &, 123 \\
\hline
\end{tabular}

\section{Hipotesis untuk kecepatan centrifuge}

$\mathrm{H}_{0}$ : efek dari kecepatan centrifuge pada level $200 \mathrm{rpm}=$ level $600 \mathrm{rpm}$ (kecepatan centrifuge tidak berpengaruh terhadap warna membran) $\mathrm{H}_{1}$ : paling tidak ada satu efek kecepatan centrifuge yang berpengaruh (kecepatan centrifuge signifikan berpengaruh terhadap warna membran).

Penolakan $\mathrm{H}_{0}$ terjadi jika nilai signifikansi pada tabel Anova lebih kecil dari nilai $\alpha$. Pada analisis ini ditentukan nilai $\alpha$ adalah 0,05. Analisis Turkey untuk faktor kecepatan centrifuge tidak muncul karena kecepatan centrifuge hanya terdiri atas 2 level, dimana jika terjadi penolakan $\mathrm{H}_{0}$ pada tabel analisis Anova, sudah dapat dipastikan bahwa level $200 \mathrm{rpm}$ dan $600 \mathrm{rpm}$ berbeda. Dengan menggunakan tingkat kesalahan $\alpha$ sebesar $5 \%(0,05)$, diperoleh nilai 
signifikansi pada Anova sebesar 0,000 yang lebih kecil dari nilai $\alpha$ sebesar 5\% (0,05). Artinya, variasi kecepatan centrifuge level $200 \mathrm{rpm}$ dan 600 rpm signifikan berbeda berpengaruh terhadap warna membran.

\section{Hipotesis untuk persen volume limbah cair}

$\mathrm{H}_{0}$ : efek dari persen volume limbah cair pada level $100 \%=$ level $75 \%$ (konsentrasi limbah cair tidak berpengaruh terhadap warna membran) $\mathrm{H}_{1}$ : paling tidak ada satu efek persen volume limbah cair yang berpengaruh (konsentrasi limbah cair signifikan berpengaruh terhadap warna membran).

Penolakan $\mathrm{H}_{0}$ terjadi jika nilai signifikansi pada tabel Anova lebih kecil dari nilai $\alpha$. Pada analisis ini ditentukan nilai $\alpha$ adalah 0,05. Analisis Turkey untuk faktor persen volume limbah cair tidak muncul karena konsentrasi limbah cair hanya terdiri atas 2 level, dimana jika terjadi penolakan $\mathrm{H}_{0}$ pada tabel analisis Anova, sudah dapat dipastikan bahwa level $100 \%$ dan level $75 \%$ berbeda. Dengan menggunakan tingkat kesalahan $\alpha$ sebesar 5\% $(0,05)$, diperoleh nilai signifikansi pada Anova sebesar 0,000 yang lebih kecil dari nilai $\alpha$ sebesar 5\% (0,05). Artinya, variasi persen volume limbah cair level $100 \%$ dan level $75 \%$ signifikan berbeda berpengaruh terhadap warna membran.

Tabel 3 - 6 adalah analisis Anova untuk keempat faktor diberikan sebagai berikut. Pada penelitian ditentukan bahwa massa paling paling baik ditentukan oleh membran yang mempunyai nilai rejeksi paling tinggi. Nilai rejeksi yang tinggi menunjukkan bahwa membran mempunyai kemampuan yang baik untuk digunakan sebagai proses filtrasi limbah. Berdasarkan tabel berikut dijelaskan bahwa level faktor yang menghasilkan nilai rejeksi warna tertinggi yaitu terdapat pada persen volume limbah cair $100 \%$, membran dengan massa silika 3\% dari massa zeolit, kecepatan centrifuge $600 \mathrm{rpm}$ dan waktu operasi membran pada menit ke-100.
Tabel 3. Pengaruh Waktu Pengujian Membran (Terhadap Nilai Rejeksi Warna)

\begin{tabular}{ccl}
\hline waktu_warna & Mean & $\begin{array}{l}\text { Std. } \\
\text { Error }\end{array}$ \\
\hline 1,00 & 58,515 & 2,147 \\
\hline 2,00 & 60,292 & 2,147 \\
\hline 3,00 & 61,672 & 2,147 \\
\hline 4,00 & 62,560 & 2,147 \\
\hline 5,00 & 65,421 & 2,147 \\
\hline
\end{tabular}

Tabel 4. Pengaruh Massa Penambahan Silika (Terhadap Nilai Rejeksi Warna)

massa_warna Mean Std. Error

\begin{tabular}{lll}
\hline 1,00 & 55,045 & 1,663 \\
\hline 2,00 & 62,691 & 1,663 \\
\hline 3,00 & 67,339 & 1,663 \\
\hline
\end{tabular}

Tabel 5. Pengaruh Kecepatan Centrifuge (Terhadap Nilai Rejeksi Warna)

\begin{tabular}{cll}
\hline kecepatan_warna & Mean & Std. Error \\
& & \\
\hline 1,00 & 53,753 & 1,358 \\
\hline 2,00 & 69,631 & 1,358 \\
\hline
\end{tabular}

Tabel 6. Pengaruh Persen Volume Limbah (Terhadap Nilai Rejeksi Warna)

\begin{tabular}{crl}
$\begin{array}{l}\text { persen } \\
\text { =warna }\end{array}$ & volume Mean & Std. Error \\
\hline 1,00 & 69,627 & 1,358 \\
\hline 2,00 & 53,757 & 1,358 \\
\hline
\end{tabular}

Penambahan silika pada membran merupakan salah satu cara untuk meningkatkan rasio $\mathrm{Si} / \mathrm{Al}$ pada zeolit (Thuadaij dan Nuntiya, 2012). Peningkatan ratio Si/Al membuat zeolit lebih hidrofobik. Hal ini menyebabkan daya adsorpsi permukaan membran terhadap air menurun (Malekpour dkk, 2011). Penurunan daya serap terhadap air membuat zeolit memiliki ruang kosong yang lebih banyak. Banyaknya jumlah ruang kosong pada kristal zeolit inilah yang membuat daya saring zeolit menjadi lebih besar (Rakhmatullah, 2007). 
Penambahan silika pada pembuatan membran memiliki pengaruh yang signifikan. Hasil uji statistik menunjukkan bahwa massa penambahan silika memilini nilai signifikansi terhadap nilai rejeksi warna. Analisis lanjut menggunakan Uji Turkey menunjukkan bahwa semua level, baik itu massa penambahan $0,5,1,5$ maupun $3 \%$ memberikan efek terhadap nilai rejeksi membran.

Berdasarkan analisa konsentrasi warna diperoleh nilai rejeksi membran paling baik didapatkan dari membran dengan massa penambahan silika sebesar 3\% dari massa zeolit. Kesimpulan ini diperkuat dengan hasil uji statistik yang menyatakan bahwa membran dengan massa penambahan silika $3 \%$ merupakan membran yang memiliki nilai rejeksi warna yang paling besar. Hal ini mengindikasikan bahwa semakin besar silika yang ditambahkan maka semakin besar nilai rejeksi membran. Besarnya nilai rejeksi membran dengan massa penambahan silika 3\% terjadi karena material membran memiliki rasio $\mathrm{Si} / \mathrm{Al}$ yang lebih tinggi.

Kecepatan centrifuge terhadap kinerja membran memberikan pengaruh yang signifikan terhadap nilai rejeksi dan fluks membran. Pengaruh yang signifikan ini dapat dilihat dari uji statistik yang telah dilakukan. Berdasarkan penelitian Citra dan Damayanti (2012), kecepatan centrifuge $600 \mathrm{rpm}$ merupakan kecepatan yang lebih baik pada pembuatan membran. Hal ini dikarenakan zeolit dan silika akan tercampur sempurna dengan kecepatan centrifuge lebih tinggi ketika dicentrifuge menggunakan pelarut 2-propanol. 2propanol dapat mencuci campuran zeolit dan silika sehingga kotoran akan terlarut dan didapatkan endapan zeoit dan silika yang lebih murni. Semakin besar kecepatan centrifuge, membuat zat-zat pengotor dapat dipisahkan dari endapan.

Berdasarkan analisis grafik yang dihasilkan, pembuatan membran dengan kecepatan centrifuge $600 \mathrm{rpm}$ memiliki nilai rejeksi warna dan nilai fluks lebih tinggi dari pada membran dengan kecepatan centrifuge $200 \mathrm{rpm}$. Hasil ini diperkuat dengan kesimpulan uji statistik. Pada uji statistik, kecepatan centrifuge memiliki nilai signifikansi rejeksi nilai fluks.

Hasil Turkey pengaruh terhadap nilai rejeksi warna menunjukkan bahwa pengaruh konsentrasi nilai rejeksi dan fluks membran memberikan nilai signifikansi hanya pada pengujian secara statistik terhadap nilai rejeksi warna dan nilai fluks. Konsentrasi limbah yang lebih baik terhadap nilai rejeksi warna pada pengujian membran adalah konsentrasi limbah cair $100 \%$. Berbeda dengan nilai rejeksi, konsentrasi limbah yang lebih baik dimiliki oleh membran dengan pengujian pada konsentrasi limbah cair $75 \%$. Selain memberikan nilai fluks paling besar, konsentrasi $75 \%$ juga memberikan penurunan nilai fluks paling kecil sehingga dapat memperlama waktu pakai membran.

\section{KESIMPULAN}

Massa penambahan silika paling tinggi pada membran filtrasi adalah 3\% dari massa zeolit. Semakin besar silika yang ditambahkan akan memperkuat membran filtrasi zeolit. Kecepatan centrifuge yang lebih baik pada pembuatan membran filtrasi adalah dengan menggunakan kecepatan centrifuge $600 \mathrm{rpm}$. Semakin besar kecepatan centrifuge akan membuat material zeolit dan silika tercampur senpurna. Membran ini lebih efektif untuk memfiltrasi limbah cair batik dari proses pewarnaan batik dengan konsentrasi $100 \%$. Kesimpulan ini diperkuat dengan hasil uji statistik yang menyatakan bahwa membran dengan massa penambahan silika 3\%, keceparan centrifuge 600 RPM dan persen limbah cair $100 \%$ merupakan membran yang memiliki nilai rejeksi membran terhadap konsentrsi warna yang paling besar, yaitu sebesar 92,68\%. Hal ini mengindikasikan bahwa semakin besar silika yang ditambahkan maka semakin besar nilai rejeksi membran. Besarnya nilai rejeksi membran dengan massa penambahan silika 3\% terjadi karena material membran memiliki rasio $\mathrm{Si} / \mathrm{Al}$ yang lebih tinggi. 


\section{DAFTAR PUSTAKA}

Ahkam. (2011), Sintesis dan Karakterisasi Membran Nanozeolit Y untuk Aplikasi Pemisahan Gas Metanol-etanol. Program Studi Ekstensi Kimia, Universitas Indonesia, Depok

Alonso, F.T., Rubio, A.M., Alvarez, R., Ortuno, J.A. (2013), Dynamic potential response and SEM-EDX studies of polymeric inclusion membranes based on ionic liquid, International journal of electrochemical science, 8, 4955-4969.

Dong, L., Yang, H., Liu, S., Wang, X and F.Xie, Y. (2015), Fabrication and Anti-biofouling Properties of Alumina and Zeolite Nanoparticle Embedded Ultrafiltration Membranes, Desalination, 365 : 7078.

Effendi, H., Sari, R. D and Hasibuan, S. (2015), Moringa oleifera as coagulant for batik effluent treatment, 15(April), 20-23.

Fadhilah, K.W., Li-Ngee, H., Soon-An, O., YeShian, W., Athirah, Y.N and Fahmi, R. (2015), Decolorization and Mineralization of Batik Wastewater through Solar Photocatalytic Proces, Int. Electrochem. Sci., 8. 11403 - 11415.

Farha, I.F dan Kusumawati, N. (2012), Pengaruh PVA terhadap morfologi dan kinerja membran kitosan dalam pemisahan warna Rhodamin-B, Prosiding Seminar Nasional Kimia Unesa, Surabaya.

Liu, Y., Zhang, S., Zhou, Z., Ren, J., Geng, Z., Luan, J and Wang, G. (2012), Novel Sulfonated Thin-Film Composite Nanofiltratiom Membrane with Improve Water Flux for Treatment Dye Solution, Journal of Membrane Sciece, 394-395.

Malekpour, A., Samadi-maybodi, A., dan Sadati, M.T. (2011), Desalination Of Aqueous Solutions by LTA And MFI Zeolite Membranes Using Pervaporation Method,
Brazilian. Journal of Chemical Engineering, (28), 999-677.

Nordin, N., Amir, S.F.M., Riyanto and Othman, M.N. (2013), Textile Industries Wastewater Treatment by Electrochemical Oxidation Technique Using Metal Plate.

Puspayana, D.R and Damayanti, A. (2013), Pengolahan limbah cair tahu menggunakan membran nanofiltrasi silika aliran cross flow untuk menurunkan kadar nitrat dan ammonium, Jurnal Teknik POMITS, 2 (2).

Rakhmatullah, D.K.A., Wiradini, $G$ and Ariyanto, N.P. (2007), Pembuatan adsorben dari zeolit alam dengan karakteristik adsorption properties untuk kemurnian bioetanol, laporan akhir penelitian bidang energi

penghargaan PT. Rekayasa industry, Program Studi Teknik Fisika, Institut Teknologi Bandung, Bandung.

Rashidi, H. R., Meriam, N., Sulaiman, N., Hashim, N. A., Rosmani, C., dan Hassan, C. (2013), Synthetic batik wastewater pretreatment progress by using physical treatment, 627, 394-398.

Setiawan, B., Rosyidin and Nurmaniwathy. (2007), Reduksi Warna dan BOD Limbah Tekstil Menggunakan Karbon-TiO ${ }_{2}$, ISSN 0216-3128.

Setyaningsih, H. (2007), Pengolahan limbah batik dengan proses kimia dan adsorpsi karbon aktif, Tesis Program Pasca Sarjana UI, Jakarta.

Thuadaij, P and Nuntiya, A. (2012), Effect of the $\mathrm{SiO} 2 / \mathrm{Al} 2 \mathrm{O} 3$ ratio on the synthesis of $\mathrm{Na}-$ xzeolite from Mae Moh fly ash. Science Asia, 38. 295-300.

Wenten, I. G. (2003), Recent development in membrane science and its industrial applications, (May). 
Yulianto, A., Hakim, L., Purwaningsih, I and Pravitasari , V.A. (2009), Pengolahan Limbah Cair Industri Batik Pada Skala Laboratorium Dengan Menggunakan Metode Elektrokoagulasi, Jurusan
Teknik lingkungan, Universitas slam Indonesia Yogyakarta, Yogyakarta.

Zhou, W., Apjarian., Lin, W dan Joy, D. (2007), Fundamentals of Scanning Electron Microscopy (SEM), Springer, New York. 